\title{
Socio-economic and environmental characterization of the residents of igarapé santa cruz, breves, arquipelago de marajó, pará, Brazil
}

\begin{abstract}
The socioeconomic and environmental problems resulting from disordered occupation on the outskirts of cities propitiate dire living conditions. In this scenario, it is important to develop studies that describe people's living conditions and the degree of environmental degradation to which they are subject. Thus, this study aims to diagnose the socioeconomic and environmental aspects of the residents living on the bank of the Santa Cruz stream that is located in the peripheral area of the municipality of Breves, Pará. The study is a quantitative and descriptive research in which the questionnaire was used to collect information on the socioeconomic and environmental profile of 257 families living in the Santa Cruz stream. The results showed that the majority of the inhabitants $(57.30 \%)$ have incomplete Elementary School; $72.36 \%$ receive less than 1 minimum wage, the main occupation is informal work, $77.82 \%$ live in houses built of wood, $68.09 \%$ of households use the water from the stream for domestic use, $48.64 \%$ of households have a sanitary destination for dry cesspits and $13,62 \%$ the sanitary destination is direct in the stream. In this context, residents live in a favorable conditions to social exclusion, unhealthiness and diseases, due to the poor socioeconomic, environmental and infrastructure conditions. Therefore, that the diagnosis of living conditions of the resident population of the stream, experience conditions of misery and abandonment.
\end{abstract}

Keywords: socioeconomics, environment, disorganized occupation, Amazon
Volume 5 Issue 3 - 2021

\author{
João Raimundo Alves Marques,' Ana Lúcia \\ Nunes Gutjahr, ${ }^{2}$ Carlos Elias de Souza Braga ${ }^{3}$ \\ 'Docente permanente da $13^{\mathrm{a}}$ Unidade Regional de Ensino \\ (URE), Secretaria de Estado de Educação do Pará - SEDUC, \\ Belém, (PA), Brasil \\ ${ }^{2}$ Docente permanente do Departamento de Ciências Naturais \\ e do Programa de Pós-Graduação em Ciências Ambientais \\ (PPGCA), Universidade do Estado do Pará - UEPA, Belém (PA), \\ Brasil \\ ${ }^{3}$ Docente permanente do Departamento de Ciências Naturais \\ (DCN), Universidade do Estado do Pará - UEPA, Belém (PA), \\ Brasil
}

Correspondence: João Raimundo Alves Marques, Docente permanente da $13^{\mathrm{a}}$ Unidade Regional de Ensino (URE), Secretaria de Estado de Educação do Pará - SEDUC, Belém, (PA), Brasil, Tel (9I) 980385980,

Email Joaoestevao.bio@hotmail.com

Received: May 18, 202। | Published: June 14, 202 I

\section{Introduction}

The socioeconomic and environmental problems arising from disorderly occupation in the outskirts of cities are possibly linked to the reality of poverty and lack of access to land. ${ }^{1}$ In this sense, the economically excluded population ends up composing poverty belts around large urban centers, settling in areas called invaded and often in default of the laws and norms established for building and land use, or in inappropriate places or prohibited to use and without any infrastructure to meet quality of life expectations. ${ }^{2}$ Therefore, the poorest groups in society are considered more vulnerable to violence, unhealthy conditions, diseases and other social problems, Although it is visible that technological advances are taking place at an accelerated pace, within the current economic process, this rapid development does not benefit all people. In the Amazon, a large part of the population still lacks basic services for a better quality of life, with insufficient housing, food and services. ${ }^{3}$ In this context, the provision of public infrastructure and sanitation services in many rural areas and urban outskirts is still precarious or non-existent, imposing on the inhabitants unhealthy conditions that cause diseases. ${ }^{4,5}$

Poverty exists in both developed and developing countries. ${ }^{6}$ However, in countries like Brazil, socioeconomic and environmental inequalities are visible, highlighting the states in the North and Northeast regions of Brazil, which have the lowest Human Development Index - HDI (IBGE, 2010). ${ }^{7}$ Thus, various areas of knowledge, such as the social sciences, propose through research possibilities to minimize poverty and social exclusion, arising from factors such as poor income distribution, low education and inefficiency in integrated public policies that address communities and municipalities in less favored regions. ${ }^{8,9}$ The municipalities of the Archipelago of Marajó show the lowest quality of life for the population in the state of Pará. These municipalities have precarious or poor sanitation infrastructure, unhealthy conditions, low education, which place the population in conditions of socioeconomic vulnerability and in the lowest HDI in the northern region. ${ }^{10}$

In the urbanization scenario in the Marajoara region, the municipality of Breves-PA stands out, where the disorderly occupation on the banks of the Santa Cruz stream is evident, whose consequences are harmful to health and the environment. In this locality, the inhabitants live in conditions conducive to unemployment, social exclusion, unhealthy conditions and illnesses. In this context, any study that addresses the living conditions, the degree of environmental degradation and the unsustainability of populations in peripheral areas becomes important. Such studies produce diagnoses that can support the implementation of public policies aimed at basic sanitation and income-generating activities, which contribute to a better quality of life for such populations. Thus, this study aims to diagnose the socioeconomic and environmental aspects of residents of the Santa Cruz stream in the city of Breves, Marajó, Pará.

\section{Meterial and methods}

The study was carried out in the Santa Cruz creek, located in the municipality of Breves, in the mesoregion of Marajó, state of Pará The municipality of Breves has an estimated population of 99,080 inhabitants and a territorial area of $9,563 \mathrm{~km}^{2}$ (IBGE, 2016). ${ }^{11}$ The Santa Cruz stream is located in the outskirts of Breves, its source is located at the geographic coordinates $50^{\circ} 29^{\prime} 12^{\prime \prime} \mathrm{W} ; 01^{\circ} 40^{\prime} 15^{\prime \prime} \mathrm{S}$ and the mouth at $50^{\circ} 29^{\prime} 26^{\prime \prime} \mathrm{W} ; 01^{\circ} 41^{\prime} 4^{\prime \prime}$ S. Currently, its bed runs along the Riacho Doce and Jardim Tropical neighborhoods on the right bank 
and in the Riacho Doce, Castanheira and Santa Cruz neighborhoods on the left bank (Figure 1). According to reports from residents, the housing process on the banks of the stream began in the 1980s, at the height of the timber industries installed in the municipality of Breves.
The methodological procedures of this study are quantitative, basic in nature and descriptive research, as it is an investigation that relates the problem and describes the phenomena involved in it. ${ }^{12}$
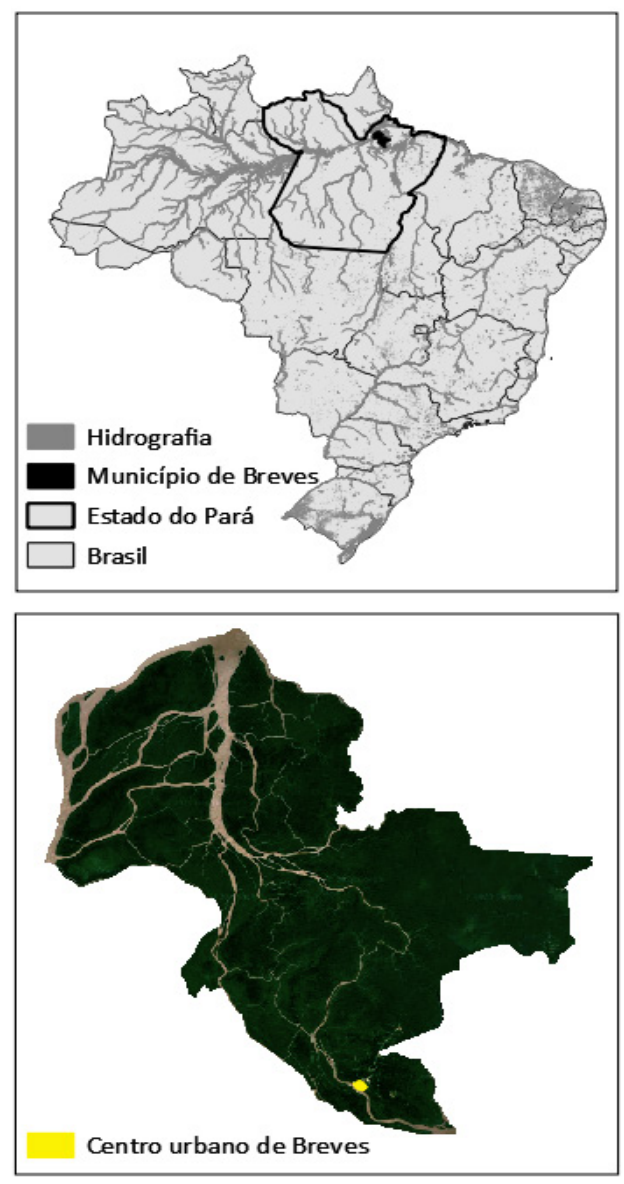

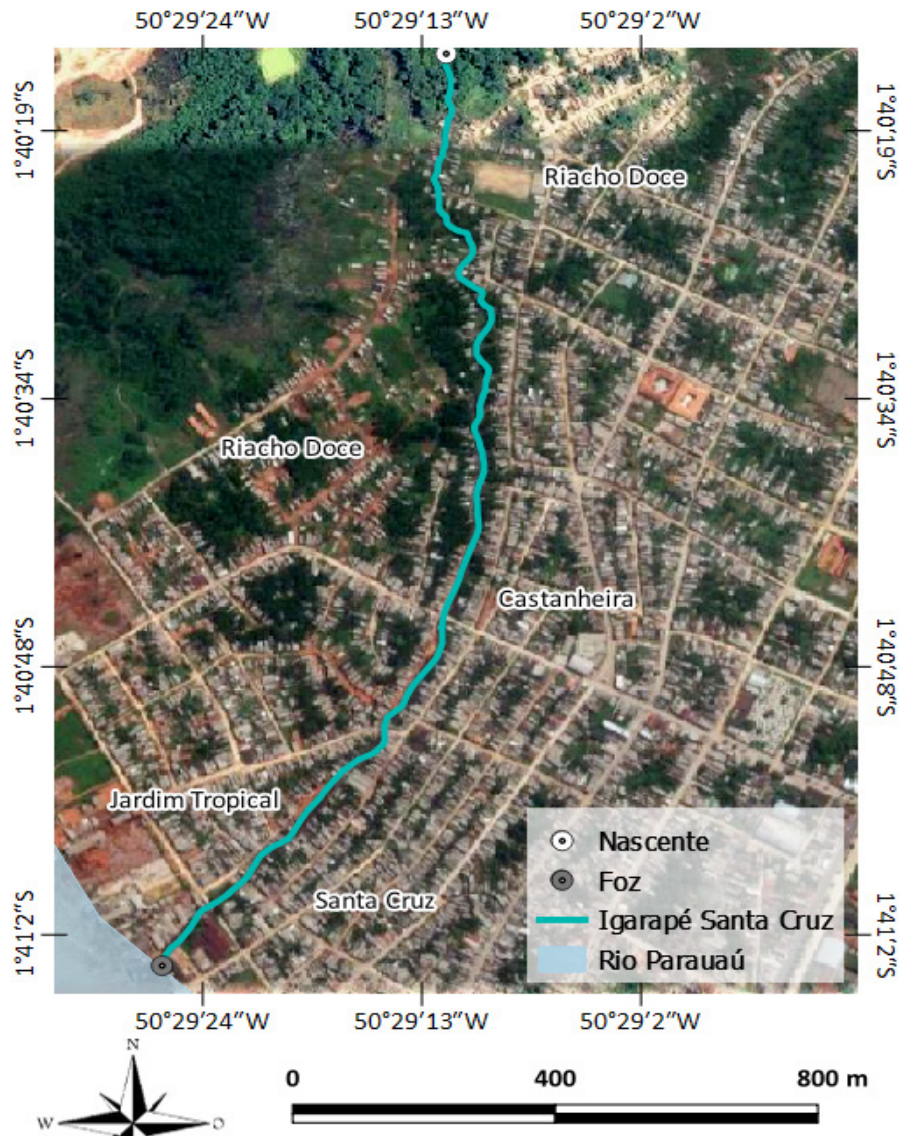

Datum: SIRGAS 2000

Base de dados: IBGE e Google Earth 08 de agos to de 2020

Figure I Location of the Santa Cruz stream, in the municipality of Breves, Pará.

For this, the study considered all the families living on the banks of the Santa Cruz stream, with 121 families on the right bank and 136 families on the left bank, totaling 257 families investigated. For one member of each family, a semi-structured questionnaire was applied, totaling 257 people who answered the questionnaire, representing $100 \%$ of the families in the study area. According to the ethicallegal precepts, this research was approved by the Research Ethics Committee of the University of the State of Pará - Campus XII Tapajós. CAAE: 63809516.9.0000.5168 whose approval opinion has the number 1.956.233. For the socioeconomic and environmental profile, a visit was made to each residence located on the banks of the Santa Cruz stream, from March 13 to April 14, 2017, on which occasion the study in question was presented to the community. Thus, one member of each family was invited to participate in the research and, after accepting the invitation, the Informed Consent Form (FICF) was delivered to the participant. The TCLE was read and signed, in accordance with the ethical-legal precepts of Resolution 466/12 II of terms and definitions - II-23 (Brasil, 2012). Only after all the clarifications were made, the structured questionnaire containing 57 closed questions was applied.

All data collected with the questionnaire were compiled into spreadsheets and analyzed in tables in the Microsoft Excel 2016 program, in addition to being statistically interpreted by the G Test (non-parametric) test at 5\% significance, using the Bioestat 5.3 software.

\section{Results}

The banks of the Santa Cruz stream are home to 1,377 people (257 families), with 660 inhabitants $(47.93 \%)$ on the right bank and $717(52.07 \%)$ on the left bank. Of the total population, $694(50.40 \%)$ are male and $683(49.60 \%)$ are female (Table 1). Predominantly, 198 families are from the municipality of Breves and 59 families are from the municipalities of Portel, Melgaço, Curralinho, Anajás and Belém. Most residents of the Santa Cruz creek belong to the age group of 20 to 29 years old ( $\mathrm{n}=257$ inhabitants; $18.66 \%$ ), followed by the age group of 10 to 14 years old $(\mathrm{n}=199 ; 14.45 \%)$ and of 15 to 19 years $(\mathrm{n}=177$ inhabitants; $12.85 \%)$ (Table 1). Regarding education, the results show a low level of education, as the majority of the population $(\mathrm{n}=789 ; 57.30 \%)$ has incomplete primary education, $129(9.37 \%)$ are illiterate and only $6(0.44 \%)$ have completed higher education (Table 1). As for school status, 67 residents $(4.87 \%)$ are enrolled in early childhood education, $426(30.94 \%)$ in primary education, 98 $(7.12 \%)$ in secondary education, $24(1.74 \%)$ in education higher and $3(0.22 \%)$ in literacy classes held by the Reference Center for Social 
Assistance (CRAS), totaling 618 of the inhabitants (44.39\%) who attend the school (Table 1). As for the occupational activities of the population, 201 residents $(14.60 \%)$ are engaged in informal work, developing services such as: general service provider, carpenter, bricklayer, stevedore, hairdresser, electrician, açaí juice seller, fruit seller. açaí/atravessador, charcoal, manicurist, shoemaker, day laborer, artisan and street vendor; 98 (7.12\%) are retirees or Social Security beneficiaries or pensioners; $65(4.72 \%)$ are salaried (bar and store attendant, sawmill, housekeeper, external delivery person, mechanic, metal worker, butcher, butcher, welder, cook, baker, clerk, nanny and watchman); $33(2.40 \%)$ are public servants; and $54(3.93 \%)$ of the inhabitants have other occupations such as motorcycle taxi driver, trader, shepherd, self-employed, fisherman and farmer.

Table I Characterization of the social profile of residents of the Santa Cruz creek, Breves, Pará from March to April/20I7

\begin{tabular}{|c|c|c|c|c|c|}
\hline Social profile & Right bank & Margin Left & Total & Percentage & Test G p-value \\
\hline \multicolumn{6}{|l|}{ Gender } \\
\hline Male & 337 & 357 & 694 & $50.40 \%$ & 0.6768 \\
\hline Feminine & 323 & 360 & 683 & $49.60 \%$ & \\
\hline \multicolumn{6}{|l|}{ Age group } \\
\hline$<1$ & 21 & 20 & $4 I$ & $2.98 \%$ & \\
\hline I to 4 & 68 & 47 & 115 & $8.35 \%$ & \\
\hline 5 to 9 & 96 & 61 & 157 & $11.40 \%$ & \\
\hline 10 to 14 & 98 & 101 & 199 & $14.45 \%$ & \\
\hline 15 to 19 & 72 & 105 & 177 & $12.85 \%$ & \\
\hline 20 to 29 & 123 & 134 & 257 & $18.66 \%$ & 0.0005 \\
\hline 30 to 39 & 64 & 85 & 149 & $10.82 \%$ & \\
\hline 40 to 49 & 52 & 59 & 111 & $8.06 \%$ & \\
\hline 50 to 59 & 35 & 42 & 77 & $5.59 \%$ & \\
\hline 60 to 69 & 21 & 33 & 54 & $3.92 \%$ & \\
\hline 70 to 79 & 7 & 19 & 26 & $1.89 \%$ & \\
\hline 80 to + & 3 & II & 14 & $1.02 \%$ & \\
\hline \multicolumn{6}{|l|}{ education } \\
\hline Children under 5 who do not attend school & 73 & 47 & 120 & $8.71 \%$ & \\
\hline Illiterate & 55 & 74 & 129 & $9.37 \%$ & \\
\hline child education & 36 & 31 & 67 & $4.87 \%$ & \\
\hline Incomplete Elementary School & 409 & 380 & 789 & $57.30 \%$ & \\
\hline Complete primary education & 4 & 3 & 7 & $0.50 \%$ & \\
\hline Incomplete high school & 48 & 86 & 134 & $9.73 \%$ & \\
\hline Complete high school & 29 & 70 & 99 & $7.19 \%$ & $P<0.0001$ \\
\hline Incomplete Higher Education & 6 & 18 & 24 & $1.74 \%$ & \\
\hline Complete Higher Education & 0 & 6 & 6 & $0.44 \%$ & \\
\hline Postgraduate studies & 0 & two & two & $0.15 \%$ & \\
\hline
\end{tabular}

More than $50 \%$ of the population residing in the Santa Cruz stream has an occupational activity without income contribution, as $164(11.91 \%)$ are housewives; $584(42.40 \%)$ are students from kindergarten to higher education and $178(12.92 \%)$ have no occupation. Emphasizing that 120 are children under the age of 5 without going to school. As for the income of the families studied, considering the current salary of R\$ 937.00 (nine hundred and thirty-seven reais), it was observed that the majority ( $\mathrm{n}=186 ; 72.36 \%)$ of the interviewees had the same monthly income or less than the minimum wage, resulting from different work occupations (Table 2$)$. It is also noteworthy that 1 family $(0.41 \%)$ had an income of four minimum wages, coming mainly from the public service (Table 2). Of the total number of families residing in the Santa Cruz stream, $201(78.21 \%)$ have a complementary family income. Among these, 193 (75.10\%) supplement the monthly balance through assistance from the Bolsa Família Program and/or Social Security Benefit (sickness or disability allowance); 6 families (2.33\%) make a salary supplement for the development of informal services; 1 family $(0.39 \%)$ through the sale of some product (popsicles, chocolates, etc.) and 1 family $(0.39 \%)$ complements the monthly income due to the employment relationship with the State. 
Table 2 Socioeconomics of residents of the Santa Cruz Breves creek, Pará: characterization of monthly family income from March to April/20I7

\begin{tabular}{|c|c|c|c|c|}
\hline $\begin{array}{l}\text { Family } \\
\text { income }\end{array}$ & Source of income & Occupation of family members & $\begin{array}{l}\text { Number of } \\
\text { Families }\end{array}$ & $\%$ \\
\hline$\leq$ I salary & $\begin{array}{l}\text { Family allowance, informal service, } \\
\text { salaried service, motorcycle taxi, } \\
\text { commerce, social security benefit, } \\
\text { closed-end insurance, pension, } \\
\text { retirement and city hall. }\end{array}$ & $\begin{array}{l}\text { Informal worker, salaried farmer, fisherman, pastor, } \\
\text { self-employed, motorcycle taxi driver, trader, } \\
\text { beneficiary, retiree, pensioner, public servant, } \\
\text { housewife and student. }\end{array}$ & 186 & 72.36 \\
\hline $\begin{array}{l}2 \text { to } 3 \\
\text { salaries }\end{array}$ & $\begin{array}{l}\text { Family allowance, informal service, } \\
\text { salaried service, mototaxi, commerce, } \\
\text { social security benefit, pension, } \\
\text { retirement and city hall. }\end{array}$ & $\begin{array}{l}\text { Informal worker, salaried worker, farmer, fisherman, } \\
\text { motorcycle taxi driver, broadcaster, sales consultant, } \\
\text { nursing technician, trader, beneficiary, pensioner, } \\
\text { retiree, public servant, housewife and student. }\end{array}$ & 70 & 27.23 \\
\hline 4 salaries & City Hall and State. & Public servant, housewife and student. & I & $0.4 \mathrm{I}$ \\
\hline
\end{tabular}

Among the interviewed families, there are 56 families $(21.79 \%)$ that have only one source of income, being 18 families $(7.00 \%)$ that depend solely on retirement; 16 (6.23\%) exclusively from federal government financial resources (Bolsa Família Program, Social Security Benefit (sick pay or Defense Insurance), 11 (4.28\%) from informal work, 7 families $(2.72 \%$ ) depend on municipal public service income and $4(1.56 \%)$ on salaried work.

As for the fishing activity on the stream, only 20 families claimed to carry out this practice, since, in most cases, this activity is carried out by children and adolescents and aims to support the family. The most common species of fish are jeju (Hoplerythrinus unitaeniatus), yam (Geophagus brasiliensis), traíra (Hoplias malabaricus), piaba (Astyanax sp), tamuatá (Hoplosternum littorale), jacundá (Crenicichla lenticulata) and shrimp (Macrobrachium amazonicum).

Regarding the housing condition of the residents, 235 families $(91.44 \%)$ have their own house on one of the banks of the Igarapé
Santa Cruz, $10(3.89 \%)$ live in a rented house and $12(4.67 \%)$ families live in house provided by family members. Among the residences, $200(77.82 \%)$ are built of wood, $16(8.56 \%)$ of reused wood and only $7(2.72 \%)$ were built of plastered masonry (Table 3$)$. The residences have an average of 2.25 potential bedrooms, excluding kitchen and bathroom, with the family group comprising an average of 5.3 people per family. As for the origin of water for household use by family members in the study area, it was found that most $(n=175)$ families $(68.09 \%)$ use water from the stream, 78 (30.35\%) use water of piped network and $4(1.56 \%)$ use river water (Table 4$)$. These families also use rainwater or water from the water truck. Water for household consumption comes from different sources, due to the precariousness or low structure of the water distribution system. Thus, only 92 families $(35.80 \%)$ use piped water, 124 families $(48.25 \%)$ fetch water from the water truck, from artesian wells or Amazon wells (common open well), river and stream and, 41 families (15.95\%) buy filtered water (purchased from a distributor) or mineral water to drink (Table 4).

Table 3 Housing conditions of the residents of the Santa Cruz stream, Breves, Pará, March to April/20I7

\begin{tabular}{lllll}
\hline Type of construction of residences & Right bank & Left margin & Total & Percentage (\%) \\
\hline Plastered masonry & two & 5 & 7 & $2.72 \%$ \\
unplastered masonry & 0 & 3 & 3 & $1.17 \%$ \\
wood & 97 & 103 & 200 & $77.82 \%$ \\
Wood and plastered masonry & 6 & 16 & 22 & $8.56 \%$ \\
Unplastered wood and masonry & 4 & 5 & 9 & $3.50 \%$ \\
reused wood & 12 & 4 & 16 & $6.23 \%$ \\
Total & 121 & 136 & 257 & $100.00 \%$ \\
\hline
\end{tabular}

Table 4 Basic sanitation characteristics of the residents of the Santa Cruz creek, Breves, Pará, March to April/20I7

\begin{tabular}{|c|c|c|c|c|c|}
\hline Sanitation variables and characteristics & Right bank & Left margin & Total & Percentage (\%) & Test G P-value \\
\hline \multicolumn{6}{|l|}{ Source of water for domestic use } \\
\hline Igarapé water & 44 & 33 & 77 & $29.95 \%$ & \\
\hline Stream water and rainwater & 44 & 49 & 93 & $36.19 \%$ & \\
\hline Water from the stream and water from the water truck & two & 0 & two & $0.78 \%$ & \\
\hline Stream water, river water and rainwater & 1 & two & 3 & $1.17 \%$ & $P=0.1415$ \\
\hline river water and rainwater & two & two & 4 & $1.56 \%$ & \\
\hline Piped water & 26 & 48 & 74 & $28.79 \%$ & \\
\hline Piped water, stream water and rainwater & two & two & 4 & $1.56 \%$ & \\
\hline Total & & & 257 & $100.00 \%$ & \\
\hline
\end{tabular}

Citation: Marques JRA, Gutjahr ALN, Braga CES. Socio-economic and environmental characterization of the residents of igarapé santa cruz, breves, arquipelago de marajó, pará, Brazil. Int J Hydro. 202I;5(3):I I5-I23. DOI: I0.I5406/ijh.2021.05.00273 


\begin{tabular}{|c|c|c|c|c|c|}
\hline Sanitation variables and characteristics & Right bank & Left margin & Total & Percentage (\%) & Test G P-value \\
\hline \multicolumn{6}{|l|}{ Source of drinking water } \\
\hline Artesian well & 13 & 13 & 26 & $10.12 \%$ & \\
\hline Artesian well and river water & 3 & 0 & 3 & $1.17 \%$ & \\
\hline Artesian well and water from the kite car & 5 & two & 7 & $2.72 \%$ & \\
\hline Artesian well and mineral water & two & 1 & 3 & $1.17 \%$ & \\
\hline Amazon well & 0 & two & two & $0.78 \%$ & \\
\hline water from the kite car & 25 & 18 & 43 & $16.73 \%$ & $P=0.0820$ \\
\hline Water from the kite car and water from the river & 5 & 4 & 9 & $3.50 \%$ & \\
\hline river water & 17 & 13 & 30 & $11.67 \%$ & \\
\hline Piped water & 38 & 54 & 92 & $35.80 \%$ & \\
\hline Filtered water (purchased) & 8 & 13 & 21 & $8.17 \%$ & \\
\hline Mineral water & 5 & 15 & 20 & $7.78 \%$ & \\
\hline Igarapé water & 0 & 1 & 1 & $0.39 \%$ & \\
\hline Total & & & 257 & $100.00 \%$ & \\
\hline \multicolumn{6}{|l|}{ sanitary sewage system } \\
\hline black cesspool & 19 & 72 & 91 & $35.41 \%$ & \\
\hline Direct on the igarapé & 5 & 30 & 35 & $13.62 \%$ & $P<0.0001$ \\
\hline dry pit & 92 & 33 & 125 & $48.64 \%$ & \\
\hline Without any type of exhaustion & 5 & 1 & 6 & $2.33 \%$ & \\
\hline Total & & & 257 & $100.00 \%$ & \\
\hline \multicolumn{6}{|l|}{ Garbage collection } \\
\hline public collection & 65 & 124 & 189 & $73.54 \%$ & \\
\hline Public collection and thrown on the creek & 1 & 0 & 1 & $0.39 \%$ & \\
\hline Public collection and burned & 18 & 8 & 26 & $10.12 \%$ & \\
\hline played on the igarapé & two & 0 & two & $0.78 \%$ & $P<0.0001$ \\
\hline burned & 33 & 4 & 37 & $14.40 \%$ & \\
\hline burned and buried & two & 0 & two & $0.78 \%$ & \\
\hline Total & & & 257 & $100.00 \%$ & \\
\hline
\end{tabular}

The treatment of water for consumption, according to the interviewees, is carried out by 198 families (77.02\%), who use piped water, water from the water truck, river water, water from an artesian well and other sources. However, this treatment in most family members is only with a chemical (aluminum sulfate), in other homes, in addition to this product, residents use hypochlorite, but there are also homes that use only hypochlorite. Family members who filter or boil water are rare. Thus, 59 families $(22.96 \%)$ consider that there is no need to carry out water treatment, as they come from artesian wells or filtered water or mineral water. As for the sanitary system, 87 residences $(33.85 \%)$ have an internal bathroom and $4(1.56 \%)$ have an external bathroom, both with toilet and waste destinations for black cesspools on the ground; 1 residence $(0.39 \%)$ has an external bathroom with toilet and disposal of waste to the stream; $159(61.87 \%)$ residences have an external bathroom without a toilet, which are built of wood with a hole in the ground without coating (dry pit) or built on the banks of the stream (Figure 2), where the feces are dumped directly into the igarapé and 6 residences $(2.33 \%)$ do not have any type of sanitary sewage.

It is noteworthy that the study area does not have a sewage system, and therefore, the organic waste of the population's physiological needs (stool and urine) is destined for dry pits (rustic house with direct excavation in the uncoated soil, intended for receive only excreta without water linkage), black pits (wells or holes dug in the ground, without waterproofing or with partial waterproofing, where raw sewage is disposed of by water) or directly into the stream (Table 3). However, 61 of the black pits and 46 of the dry pits are located 2 to 5 meters away from the stream. Regarding the garbage produced by the inhabitants, the results show that 189 families $(73.54 \%)$ put household waste for public collection, 37 (14.40\%) reported burning the garbage, mainly in the Amazon summer, where the water level of the igarapé is lower and 3 families (1.17\%) dump their household garbage directly into the igarapé (Table 03). Although most of the population reported public collection and that it takes place twice a week, there was a lot of garbage thrown in the stream, including dead animals such as dogs and cats (Figure 3 ). 


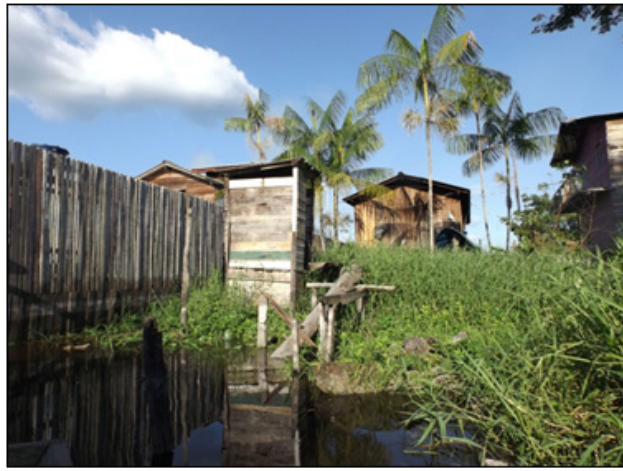

A)

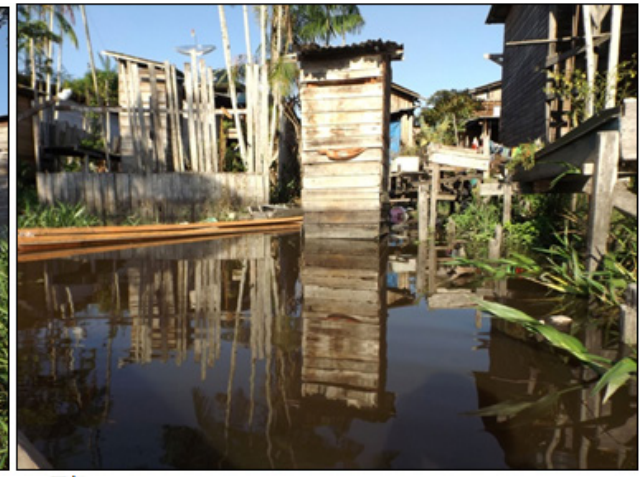

B)

Figure 2 Aspect of the bathrooms in the Santa Cruz stream, Breves, Pará from March to April/20I7.A) restroom located on the banks of the Santa Cruz stream. B) restroom located inside the Santa Cruz stream, next to the dishwasher.

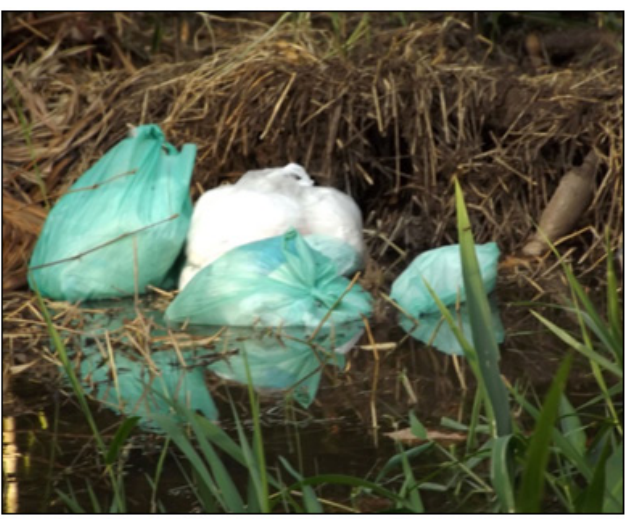

A)

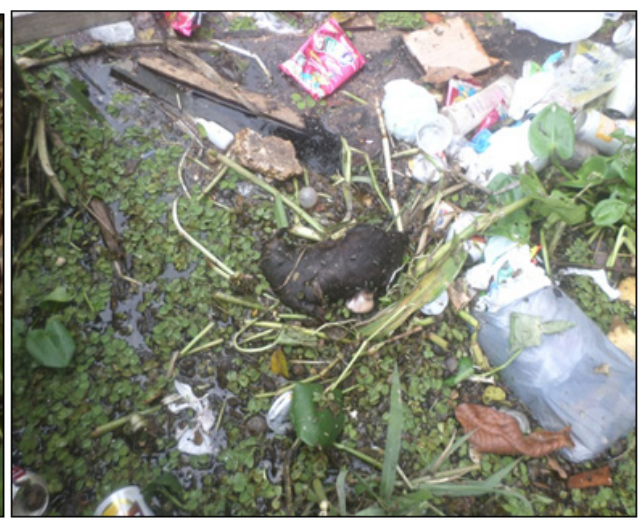

B)

Figure 3 Aspect of solid waste in the Santa Cruz stream, Breves, Pará from March to April/20I7:A) plastic bags with garbage floating in the waters of the Santa Cruz stream. B) various garbage scattered around the Santa Cruz stream and a dead animal floating.

\section{Discussion}

As observed in this study, the inhabitants of the right bank of the Santa Cruz stream have the lowest levels of education compared to those on the left bank $(\mathrm{p}<0.05)$. However, almost all people residing in the Santa Cruz creek have only basic education, which reflects the low level of education in the region, which contributes to the low human development index (HDI) recorded for the municipality of Breves, which is one of the smallest in the state of Pará. ${ }^{13}$

Studies carried out by Alves et al. ${ }^{14}$ in rural communities in the municipality of Marapanim-PA, Araújo et al. ${ }^{15}$ in a quilombola community in the municipality of Ananindeua-PA and Guimarães, Pereira et al. ${ }^{16}$ in rural communities of the Caeté River basin in the State of Pará, which presented similar conditions, observed numbers close to those found. in Breves, which the authors classified as a low level of education. In this sense, it is important to emphasize that low education is a restrictive element to human development, due to the reduced ability to assimilate new knowledge, a condition that contributes to limiting people's social, economic and productive ascension. ${ }^{17,18}$

The population's low level of education allows us to infer that adolescents, young people and adults end up dropping out or giving up on their studies due to precarious living conditions. This condition supports their entry into the informal labor market. To the detriment of education, people only get jobs that require less qualifications, in which they earn less and, as a result, they are likely to be parents of children with no prospect of quality of life, reproducing poverty between generations. ${ }^{19}$ People with a low level of education belong to a context of responsibility aimed at meeting their living needs (subsistence), which makes them give up school life. ${ }^{20}$ Many people in this condition are part of a work reality with intense physical activity (manual work) and exhaustive work hours, mainly due to the need for a favorable source of income in the home economy and family support. Such work situation distances them from school and, in other cases, makes them simply lose interest in studying.

It is noteworthy that education is a decisive factor for the development of the individual and also of a society, as it promotes democratization, gives access to cultural heritage and higher positions in the select labor market, and must also consider that certain attitudes of an individual is influenced by the degree of institutional education. ${ }^{21}$ Therefore, when you have access to education, a range of possibilities opens up, whether in the material or intellectual aspect, in addition to providing new horizons and improving people's lives. ${ }^{22}$ However, according to Silva ${ }^{23}$ it is possible to state that one of the factors that most contributes to the lack of access to education in Brazil is the inequality of income distribution. This factor compromises the entire educational structure. Considering the aforementioned social aspects and considering the economic factor of the residents of the Santa Cruz creek, it can be admitted that the Bolsa Família Program is extremely important, since this benefit means an important income in the local economy, ${ }^{24}$ although the resident population of the Santa Cruz stream is living in a vulnerable situation. Study by Alves et al. ${ }^{14}$ carried out with rural communities in the municipality of Marapanim-PA, states that the financial resources destined to the low-income population, 
through the Bolsa Família Program, contributes to the increase in income and to the well-being of the families served. In this way, this financial resource serves to complement the residents' family budget.

There are situations in which the family income of residents of the Santa Cruz stream does not meet all household needs, even with the complement of financial assistance from the Bolsa Família Program. This fact is mainly due to the number of people in the residence, the lack of occupation by family members and the low level of education. These families often do not have their own daily support, needing, at times, to resort to fishing activities on the stream. In this activity, children and teenagers are the ones who support the family. Thus, it is necessary to implement new social policies and improve existing ones, as they are essential elements to achieve a better quality of life and a less unequal society. ${ }^{23}$

In the housing aspect, the characterization of the type of domicile and housing is an important indicator of the conditions and quality of life of the population..$^{15}$ In this sense, the data in this study indicate, in general, that the homes of the interviewees have poor sanitary and infrastructure conditions, with the majority being rustic houses built of wood and some of reused wood, that is, these homes do not have full comfort and durability. In this regard, Pinheiro ${ }^{9}$ consider households to be durable, as at least two of the three housing components - roof, walls and floor - are made of durable materials, such as those found in masonry constructions.

The water distribution system in the municipality of Breves is the responsibility of the Sanitation Company of the State of Pará (COSANPA). However, unplanned urbanization caused a problem in the distribution of water to the neighborhoods further away from the city center. Thus, part of the population of brevense suffers from a lack of water, as is the case of most residents of the Santa Cruz stream. Therefore, the water used for consumption and domestic use by most residents, both on the right and left banks, without any statistically significant difference $(p>0.05)$, comes from artesian or amazon wells, river, rain, kite car and the stream itself. Few people use piped water, as the distribution system is deficient.

The precarious situation of water distribution for the inhabitants of the Santa Cruz stream can lead to serious public health problems regarding the use of surface water, since, according to Marques et al., ${ }^{2.5}$ the waters of this water body contain a high level of contamination by disease-causing organisms, according to these researchers, the level of contamination is so high that the surface waters of the aforementioned stream fall within the classification of the National Council for the Environment (CONAMA), Resolution No. 357/05 ( Brazil, 2005) as class 4 , that is, they must be intended only for navigation and landscape harmony, being unsuitable for domestic use or consumption. The researchers detected concentrations of fecal (thermotolerant) coliforms between 4,352 NMP/100 mL at high tide and 111.Thus, the Santa Cruz creek, as a whole, receives punctual direct and indirect sewage discharges, which contributes to its high coliform values, as a result of dry and black pits located less than five meters away. In addition, the existence of toilets located on the banks or inside the stream should be considered, whose flow of human waste, together with rainwater and household water from other neighborhoods of the city, which are carried by sewage (open air) to the creek bed. Thus, the determination of the concentration of coliforms assumes importance as a parameter indicating the existence of pathogenic microorganisms responsible for the transmission of various diseases, including: worms, amoebiasis, giardiasis, cryptosporidiasis, typhoid fever, cholera and hepatitis A. ${ }^{26,27}$ It is important to highlight that the treatment of water for consumption from the river, stream or piped is not always carried out properly by the interviewed residents, since part of the population living in the Santa Cruz stream only uses aluminum sulphate, a chemical in which It is used for decanting dense particles present in water and not for combating microorganisms such as bacteria, protozoa and others.

Sanitation actions reduce the occurrence of diseases and prevent damage to the environment, especially to soils and water bodies. According to Kronemberger, Pereira, Freitas, Scarcello and Clevelario $\mathrm{Jr}$ (2011), 30.5\% of Brazilian municipalities discharge untreated sewage into rivers, lakes or lakes, and use these receiving bodies for various downstream uses, such as in supply water, recreation, irrigation and aquaculture. These authors also admit that from these municipalities, $16 \%$ discharge untreated sewage into water bodies that are used downstream for human supply, corroborating the results obtained in this study for the Santa Cruz stream.

The municipality of Breves topresent only $6.1 \%$ of households with adequate sanitation and $2.9 \%$ of urban households on public roads with adequate urbanization with the presence of manholes, sidewalks, pavements and curbs. In these aspects, when compared to the 144 municipalities in the State of Pará, Breves is in the 91st and 57th position, respectively.(IBGE, 2010). These data demonstrate how deficient the city's basic sanitation is, however, this reality is present in most states that make up the Legal Amazon. Although there has been an increase in access to sanitation services, the percentage of sanitary coverage in the Amazon region is much lower than in other regions of Brazil. ${ }^{28}$

Another problem observed along the Santa Cruz stream is the presence of waste (organic, plastic, metal, glass), as well as on the sides or under the floor of the houses. This reality is opposed to the results obtained in the interviews, as there is a large amount of waste deposited in the water, for only three families who declared to dump their garbage in the stream. Therefore, it is clear that a large part of the population has neither sensitivity nor perception about the level of environmental degradation they are causing. In this context, it can be considered that Environmental Education is the most appropriate alternative to sensitize the population about environmental problems and promote changes in habits and behaviors that are harmful to the environment. ${ }^{29}$ Furthermore, The population's lack of awareness in relation to garbage increases the degree of vulnerability of people, not only in relation to the perception of health risk, but also in terms of public cleaning. ${ }^{30}$ Where people live influences their health and their ability to enjoy a prosperous life. Therefore, shelter, quality housing, clean water and adequate sanitary conditions are human rights and basic needs for a healthy life.

According to Law No. 11,445/2007, basic sanitation is the set of services, infrastructure and operational facilities related to four processes that include, drinking water supply, sanitary sewage, urban cleaning and solid waste management, and drainage and water management rainwater (Brazil, 2007). Thus, guaranteeing these rights is one of the concerns of policies to combat poverty and improve people's quality of life, as the quality, availability and accessibility of the population to basic sanitation are essential for human development. ${ }^{17}$ While people who are more financially privileged or wealthy generally inhabit adequate and relatively safe areas, from an environmental point of view, the less financially privileged (poor) most often live in precarious housing in places with situations of risk and environmental degradation, which generally they are accompanied by terrible conditions of urban and sanitary infrastructure, ${ }^{28,30}$ considering that they are often consequences of their own habits.

Studies similar to this one, carried out in quilombola communities, ${ }^{15}$ rura $^{16}$ and in peripheries close to dams ${ }^{32}$ corroborate the results 
obtained in this study, with regard to the precarious conditions of housing, socioeconomic, infrastructure and environmental degradation. Thus, it is noteworthy that since the nineteenth century, there has been more evidence that the health conditions of a population are related to the characteristics of the social, economic, political, cultural and environmental context in which they live. ${ }^{33,34}$ As for the above, it can be admitted that the health problems arising from socioeconomic and environmental conditions in the Amazon region seem to be far from being resolved, as aspects such as poverty, precarious housing conditions, the inadequate urban environment and the Unhealthy working conditions are factors that negatively affect the quality of life of a population..$^{34-42}$

\section{Conclusion}

The Santa Cruz creek had its occupation in disarray as a result of the search for work/employment at the height of the timber industry in the municipality of Breves. This search triggered inadequate housing facilities on the banks of the stream. Today, the population living there has been suffering from the logging crisis and is looking for new income alternatives to meet the family's needs. Given this reality, it is evident that residents have low purchasing power due to the low level of education (schooling), which limits the options for better paid work. In this way, most of the population is induced to opt for informal work, which conditions the need for supplementary income, especially from the Bolsa Família Program. Most of the families studied do not have basic services, such as running water and adequate sanitary sewage. In addition, people living on the Santa Cruz stream need Environmental Education practices in order to minimize the environmental damage they cause to the stream. In this context, the action of government actors is necessary, so that public policies can be developed aimed at improving the quality of life of this population, whether through the implementation of sanitation infrastructure, generation of employment and income or encouragement of education . Given the specificities of the aspects diagnosed in this study, it can be inferred that most people living on the banks of the Santa Cruz stream, in general, have a low quality of life.

\section{Acknowledgments}

None.

\section{Conflicts of intetest}

The author delares there is no conflict of intetest.

\section{References}

1. Barbosa AF, Araújo JS, Bezerra IS. Analysis of the socio-environmental vulnerability of the municipality of Cabedelo PB. Environmental Magazine. 2016;2(2):14-25.

2. Zanella ME. Floods in Curitiba: social and environmental impacts, risk and vulnerability. (Collection of Postgraduate Studies), UFC Editions, University Press, Fortaleza, CE. 2014.

3. Chagas MA, Santos JSA, Silva EL. Environmental Policy: the neglect of the urban in the Amazon. PRACS: Electronic Journal of Humanities of the Social Sciences Course at UNIFAP. 2016;9(1):127-136.

4. Fonseca EOL, Teixeira MG, Barreto ML, et al. Prevalence and factors associated with geohelminthiasis in children living in municipalities with a low HDI in the North and Northeast of Brazil. Caderno da Saúde Pública. 2010;26(1):143-152.

5. Souza RS, Souza LS, Souza NJ, et al. Basic sanitation in the state of Roraima: current situation and perspectives. Analysis. 2010. p. 151-161.
6. Werthein J, Noleto MJA. UNESCO and its commitment to development and combating poverty. Proceedings of the International Seminar on Poverty and Inequality in Brazil, Brasília, Brazil. 2013. p. 8.

7. BRAZILIAN INSTITUTE OF GEOGRAPHY AND STATISTICS - IBGE. 2010 Census. 2017.

8. Fahel M, Teles LR, Caminhas DA. Beyond Income: An Analysis of Multidimensional Poverty in Brazil. RBCS. 2016;31(92):1-21.

9. Pinheiro JOC, Darnet LAF. Traditional communities in coastal areas of the Amazon: a study on local development in Vila Mota, Pará. Brazil.Bol. For. emile Goeldi. Science Hmm. 2014;9(1):145-162.

10. Ferreira PRC, Castilho SR, Pantoja EG, et al. Environmental education in Marajoara municipalities and peripheral and riverside regions of an Amazonian capital: Research and extension in situational characterization. Annals VI national meeting of ANPPAS. Belém, PA, Brazil, 2012. p. 18.

11. BRAZILIAN INSTITUTE OF GEOGRAPHY AND STATISTICS - IBGE. Atlas of Human Development in Brazil. 2016.

12. Kauark FS, Manhães FC, Medeiros $\mathrm{CH}$. Research methodology: a practical guide. Itabuna, Bahia: Via Litterarum. 2010.

13. Caetano VNS, Silva AN. Development and education in Marajó: case study in the municipality of Breves (Marajó/Pará/Brazil). Revista GeoAmazônia. 2016;4(7):120-137.

14. Alves, RJM, Pontes AN, Gutjahr ALN. Socioeconomic characterization of Amazonian rural communities in the state of Pará, Brazil. Observatorio Economía Latinoamericana, 2015. p. 210.

15. Araújo AS, Anjos DR, Silva RS, et al. Socioeconomic analysis of farmers in the Abacatal quilombola community, Ananindeua, Pará state, Brazil. Amazon Biota. Macapá. 2017;7(1):30-37.

16. Guimarães DO, Pereira LCC, Monteiro MC, et al. Socioeconomic and Environmental Aspects of Rural Communities in the Caeté River Basin (Pará-Brasil). Journal of Integrated Coastal Management. 2009;9(2)71-84.

17. Cruz FRS, Sousa FQ, Oliveira CJ, et al. Socioeconomic vulnerability in rural communities in the municipality of Areia, State of Paraíba. Scientia Plena. 2013;9(5):01-10.

18. Pacheco MMDR, Silva AL, Silva JE, et al. School dropout in the microregion of Guaratinguetá: an analysis based on educational indicators. ECCOM. 2016;7(14):169-189.

19. Ávila AS. Child labor and school absence. Brazilian Journal of Education. 2007;12(34):68-80.

20. Fritsch R, Vitelli RF. School dropout, school and the job market: what high school youth from public schools say. Proceedings XI ANPED Regional Scientific Meeting. Curitiba, PR, Brazil, 2016. p. 24.

21. Carvalho AP. Study of environmental degradation in the basin of the Açude Soledade-PB. Doctoral Thesis in Agricultural Engineering, Federal University of Campina Grande, Campina Grande, SP, Brazil. 2010.

22. Silva DDE, Moraes Neto, JM Rios, et al .Analysis of socioeconomic vulnerability around the hydraulic basin of the Jatobá II reservoir, in the semiarid region of Paraibano. Brazilian Journal of Physical Geography. 2017;10(2):402-412.

23. Milanez ACS, Silva CML. The importance of Bolsa Família on the economy of the Municipality of Antônio Gonçalves - Bahia. Multidisciplinary and Psychology Journal. 2016;10(30):34-47.

24. Rosinke JG, Heck CR, Dalfovo WCT, et al. Social and Economic Effects for Local Development through the contributions of the Bolsa Família Program in the municipality of Sinop-MT from 2004 to 2009. INTERACTIONS. 2011;12(1):77-88. 
25. Marques JRA, Nunes-Gutjahr AL, Braga CES. Sanitary situation and use of water in the Igarapé Santa Cruz, municipality of Breves, Marajo Archipelago, Pará, Brazil. Sanitary and Environmental Engineering. 2020;25(4):597-606.

26. Cabral JPS. Water Microbiology. Bacterial Pathogens and Water International Journal of Environmental Research Public Health. 2010;7(10):3657-3703.

27. Santos PP, Miranda TMT, Barthassson DL, et al. Microbiological quality of effluents and effluents from water and sewage treatment plants in Goiânia, Goiás. Revista de Patologia Tropical. 2010;39(3):173-187.

28. Viana RL, Freitas CM, Giatti LL. Environmental health and development in the Legal Amazon: socioeconomic, environmental and health indicators, challenges and perspectives. Saúde Soc. São Paulo. 2016;25(1):233-246.

29. Nunes MER, France LF, Paiva LV. Effectiveness of different strategies in teaching environmental education: association between research and university extension. Ambiente \& Sociedade. 2017;20(2):61-78.

30. Medeiros MD, Almeida LQ. Social and environmental vulnerability in the city of Natal, RN, BR. NETWORK - PRODEMA Electronic Magazine. 2015;9(2):65-79.

31. Esteves CJO. Social and environmental risk and vulnerability: conceptual aspects. Cad. IPARDES, Curitiba. 2011;1(2):62-79.

32. Silva, WA. School dropouts in high school in Brazil. Education in Focus. 2016;19(29):13-34

33. Braveman P, Gottlieb L. The Social Determinants of Health: It's Time to Consider the Causes of the Causes. Public Health Rep. 2014;129(2):19-31.

34. Barreto ML. Health inequalities: a global perspective. Ciência \& Saúde Coletiva. 2017;22(7):2097-2108.

35. Carvalho A. Social, economic and environmental determinants of health In OSWALDO CRUZ FOUNDATION. Health in Brazil in 2030 - strategic prospection of the Brazilian health system: population and health profile. Rio de Janeiro: Fiocruz/Ipea/Ministry of Health/Department of Strategic Affairs of the Presidency of the Republic. 2013;2:19-38.
36. Brazil, Law No. 11,445, of January 5, 2007(2007). Law on National Basic Sanitation Guidelines. 2007.

37. Brazil. Resolution No. 357/2005. Provides for the classification of water bodies and environmental guidelines for their classification, as well as establishes the standard conditions for the release of effluent. promulgated on March 17, 2005.

38. Brazil, Resolution No. 466, of December 12, 2012. Resolution incorporates, from the perspective of the individual and collectives, references of bioethics, such as autonomy, non-maleficence, beneficence, justice and equity, among others, and aims to ensure the rights and duties that concern research participants, to scientific community and the State. 2016 .

39. Gonçalves KS, Siqueira ASP, Castro HA, et al. Indicator of socioenvironmental vulnerability in the Western Amazon. The case of the municipality of Porto Velho, Rondônia, Brazil. Ciência \& Saúde Coletiva. 2014;19(9):3809-3817.

40. Koch FF, Kauffmann C, Bica JB. Analysis of surface water for human consumption in a municipality in Rio Grande do Sul. Caderno Pedagógico, Lajeado. 2017;14(1):36-50.

41. Kronemberger DMP, Pereira RS, Freitas EAV. Sanitation and Environment. In. Brazilian Institute of Geography and Statistics - IBGE. Atlas of Sanitation 2011. Rio de Janeiro. 2011

42. Rosa SV, Lustosa MC. Socio-environmental vulnerability database of the metropolitan region of Fortaleza - Ceará. In: Lustosa, MC, et al., editors. Social and environmental vulnerability in the metropolitan region of Fortaleza. (Geographic Studies Collection), UFC Editions, Fortaleza, CE. 2009. 